\title{
Semantic Domain of Hand Activity to Hold in Mandailing Language
}

\author{
Anharuddin Hutasuhut ${ }^{1}$, Waridah ${ }^{2}$ \\ ${ }^{1}$ Faculty of Social Science and Political Science, Universitas Medan Area, Medan, Indonesia \\ ${ }^{2}$ Language Institution of Sumatera Utara, Medan Indonesia \\ anhary_suhut@yahoo.com
}

\begin{abstract}
This research is based on research data in the form of lexemes or words that express the concept of hand activity in Mandailing language. The data of this study are a number of Mandailing language lexemes which contain the meaning of hand activity. All data obtained is recorded and ordered. The data that has been recorded on the data card is classified based on the similarity of the lexical semantic component. The lexemes which stated the hand activity in Mandailing language which had been inventoried were eighty-five lexemes. These lexemes are classified based on the components of the meaning they have so as to form groups or more sub-domain specific meanings. From the study, there were twenty groups of sub-domain meanings based on the purpose of the activity, namely (1) holding, (2) touching, (3) taking, (4) carrying, (5) laying, (6) throwing, (7) giving, (8) receiving, (9) opening, (10) closing, (11) pulling, (12) pushing, (13) hurting, (14) destroying, (15) rolling, (16) calling out, (17) expelling, (18) ) blocking, (19) greeting, and (20) pointing.
\end{abstract}

Keywords: Semantic domain; hand activity; Mandailing language.

\section{Introduction}

Starting from the formulation of the problem and the purpose of the study, twenty subdomain were found in this study. Some sub- domain have only one lexeme and some have more than one lexeme. Sub- domain that only have one lexeme, namely (1) giving, (2) receiving, (3) calling, (4) casting out, (5) greeting, and (6) pointing. These six sub- domain certainly do not have what is called the superordinate lexeme and subordinate lexeme. Meanwhile, other sub- domain which have two or more lexemes usually one of the lexemes becomes superordinate and the other becomes a subordinate lexeme. However, there are also sub- domain who have two or more lexemes but do not have superordinate lexemes. Subdomain like this are called sub- domain with superordinate zero.

Sub-domain of hand activity to hold has nine lexemes. Judging from the components of meaning it possesses, the tiop "hold" lexeme is the superordinate in this group. The classifying semantic characteristic owned by the tiop lexeme and which also characterizes the semantics of the lexeme subordinates is the existence of a component of hand activity and a component of the meaning of the target's purpose.

Sub-domain of hand activity to touch has four lexemes. The superordinate in this group is the jama "touch" lexeme. The classifying semantic characteristic of this group is the presence of a component of hand activity and a component of the meaning of the target purpose touched.

Sub-domain of hand activity to take has ten lexemes. The superordinate in this group is buat "take". The classifying semantic characteristic of this group is the existence of a component of hand activity and a component of the meaning of the purpose objectives taken.

Sub-domain of hand activity to carry has three lexemes. The superordinate in this group is lexeme oban "carry". The semantic characteristic of this group is that there is a component of the hand activity and a component of the meaning of the intended purpose. 
Sub-domain of hand activity to put down has four lexemes. This group does not have lexemes which are its superordinate. In other words, sub-domains are a group of lexemes with zero coordinates. However, the lexeme still have similar meanings or intersect with one another.

Sub-domain of hand activity to throw has three lexemes. The superordinate in this group is ramban "throw" lexemes. The semantic characteristic of this group is that there is a component of hand activity and the target meaning component is thrown.

Sub-domain of hand activity to open has three lexemes. The lexeme supervised in this group is "open" lexeme. The semantic characteristic of this group is that there is a component of hand activity and a component of the meaning of an open target purpose.

Sub-domain of hand activity to close has three lexemes. The lexeme supervised in this group is "close" lexeme. The classifying semantic characteristic of this group is the presence of a component of hand activity and a component of the meaning of a closed target purpose.

Sub-domain of hand activity to pull has five lexemes. The lexeme supervised in this group is "pull" lexeme. The semantic characteristic of this group is that there is a component of hand activity and a component of the meaning of the target's interest.

Sub-domain of hand activity to push has three lexeme. This group or sub-domain does not have a lexeme as the superordinate. In other words, sub-domains are a group of lexemes with zero coordinates. However, the lexeme contained in this group still have similar meanings or intersect with one another.

Sub-domain of hand activity to hurt has nineteen lexemes. This subject can be further divided into three groups, namely (1) hand activity to hurt the head and parts of it having eight eczema, (2) hand activity to hurt the neck having one lexeme, and (3) hand activity to hurt the the body having ten lexeme. The classifying semantic characteristic of the three groups above is the existence of a component of hand activity and a component of the meaning of the intended goal of being hurt.

Sub-domain of hand activity to destroy has nine lexemes. This group does not have lexemes which are its superordinate. In other words, sub-domains are a group of lexemes with zero coordinates. However, the lexemes in this group still have similar meanings or intersect with one another. The classifying semantic characteristic of this group is the existence of a component of hand activity and a component of the meaning of the purpose of the target being destroyed.

Sub-domain of hand activity to roll has two lexemes. This group does not have lexemes which are its superordinate. However, the lexeme contained in this group still have similar meanings or intersect with one another. The semantic characteristic of this group is that there is a component of hand activity and a component of the meaning of the objectives being rolled up.

Sub-domain of hand activity to inhibit has two lexemes. The lexemes supervised in this group is olat "inhibit" lexeme. The classifying semantic characteristic of this group is that there is a component of hand activity and a component of the meaning of the target goal is inhibited.

From the discussion above it can be said that the findings of this study indicate that semantic domain of hand activity is in line with the study put forward by Lehrer (1974). A set of lexemes belonging to one field of meaning is described in terms of its meaning components, both with respect to the common component (generic) and the distinguishing component (specific). 
To determine the components of distinguishing meanings or find more specific meanings, the analysis of meaning components is used. Analysis of the meaning components is elaborated from each lexeme by determining the metallic formulation. In determining the formulation of meta-language guidelines are used as a concept, namely using the hands or fingers, methods, goals, frequency, and objectives of the activity. The order of the concepts is not the same from each field.

The lexeme studied in this study only deals with common meanings, although sometimes it also has metaphorical meanings, as shown in the following example.

Ise do sannari maniop parusahaan i?

siapa sekarang memegang perusahaan itu

'Siapa memegang perusahaan itu sekarang?'

"Who holds the company now?"

The maniop lexeme in the above sentence does not contain the usual meaning 'hand activity to hold something (object)', but has a metaphorical meaning 'lead or manage'. The meaning of metaphors like the example above is not the scope of this study.

\section{Literature Review}

\subsection{Lexeme}

This research is based on research data in the form of lexemes or words that express the concept of hand activity in Mandailing language. In other words, the object of this research is the expressions of hand activity in Mandailing language. For this reason, it is necessary to emphasize the concept of lexeme which is the basis of this research. According to Kridalaksana (1982: 98), lexemes are basic abstract lexical units that underlie various inflective forms of a word. This opinion is in line with Mattheus (in Nurlina, 1993: 10) who formulated the lexeme as a set of abstract units that underlies grammatical variation.

According to Basiroh (1992: 20), based on possible lexical forms, lexemes can be either lexeme simplex or complex lexeme. The simplex lexeme is seen in the 'pinch' shape of the cibit, while the complex lexeme is seen in the 'hit' shape.

The meaning analyzed in this study is lexical meaning. According to Pateda (1989: 64) lexical meaning is the meaning of the lexeme when the lexeme stands alone. In line with the opinion of Pateda, Kridalaksana (1982: 110) said the lexical meaning is the meaning possessed by the elements of language apart from its use or context. Furthermore, Alwasilah (1984: 147) says that the lexical meaning is the meaning that is ordinary, objective, has not been overshadowed by feelings, values, and a certain taste. Then, Chaer (1994: 60) says that lexical meaning is the meaning that is in accordance with the referent, the meaning that is in accordance with the results of the observation of the senses, or meaning that is really real in our lives.

\subsection{Semantic Domain}

What is meant by the semantic domain or semantic field is a set of meanings containing the same components of general meaning. This understanding is in line with the opinion of Kridalaksana (1993: 105) which states that the semantic domain is part of life or reality in a particular universe and which is realized by a set of lexical elements whose meaning is related. 
Lehrer (1974: 1) mentions that semantic domain is a group or a number of semantically related lexemes which are generally covered or sheltered by a lexeme that is superordinate and words that are subordinate to common words as hyponyms. Furthermore, Lehrer (1974: 347) says that a group of lexeme will form a field if it contains components of shared meaning.

The concept of the semantic domain Lehrer (1974) matches the concept of the realm of meaning or the semantic domain of Nida (1975). According to Nida (1975: 174), the realm of meaning consists of a set of meanings that have the same general meaning components. Furthermore, Nida (1975) said that the analysis of meaning components can be performed on lexemes in a field by describing them up to the smallest meaning components.

Loursbry $(1964,1973)$ states, the kinship lexicon of each language forms a field of meaning and that field of meaning is a paradigm formed from the lingual form.

Uhlenbeck (1982: 43) says, the semantic domain is an area occupied by a number of words that have a meaning relationship, but they remain in opposition. Furthermore, Uhlenbeck also said that there are no synonyms, that is, there are never two words that have the same meaning, there are always differences, of course there is a possibility of limited equality.

\subsection{Hand Activity}

The limitation of understanding of hand activity in this study is based on the understanding of hand and activity, as described in Indonesia Dictionary (KBBI). In KBBI (2005: 1136), the word hand is given meaning: limbs from the elbow to the tip of the finger or from the wrist to the tip of the finger. Furthermore, in KBBI (2005: 23), the word activity is given the meaning of: (1) activity, activity; (2) work or one of the work activities carried out in each part of the company. From the active and active understanding it can be concluded that activity is the ability of something to act or react.

Based on the understanding of hands and the activities described above, it can be formulated that the definition of hand activity can be defined, namely the ability of the limbs from the shoulder to the fingertips to carry out actions or reactions.

As one understanding, the above limits are very clear. However, as a limitation, this understanding is too loose. With this understanding, every lexeme of hand activity in the Mandailing language must be raised as data. For example can be mentioned the lexeme jomput take or hold with fingertips lexeme, umpat pull out or lift up using fingers, tenju hit with clenched fingers, cibit or pinch, and pulos or pinched and then rotated. By limiting the understanding of hand activity as the ability of the limbs from the shoulder to the fingertips to carry out an action or reaction, the five lexemes must be raised as data in accordance with the role of hand activity in the implementation of their actions. On the other hand, if you pay attention, the five lexemes can still be grouped into several groups based on the presence or absence of participation of instruments or organs. The lexemes of jomput, umpat, tenju, cibit, and pulos can be grouped into activities where the implementation of their actions can be carried out with or without assistive devices.

Based on the examples and the description above, it can be said that in Mandailing language there are various groups of lexeme expressing hand activity seen from the dimensions of the presence or absence of aids, the presence or absence of participation organs, or the presence or absence of tools and organs of non-hand. Because of the diversity of types and roles of the hands in various actions, in this study the definition of hand activity 
is specified again based on that aspect. Thus, the definition of hand activity in this study is specifically on the ability of the limbs from the shoulders to the fingertips to carry out actions or reactions that do not require the existence of assistive devices or the participation of other body parts.

\section{Research Methods}

The data of this study are a number of Mandailing language lexemes which contain the meaning of hand activity. Data sources include oral data and written data. Written data were obtained from the Angkola / Mandailing Language Dictionary - Indonesia compiled by Ahmad Samin Siregar (1977). Meanwhile, oral data were obtained from various conversations that took place in the Mandailing community in Mandailing Natal District.

The collected data was refined through informants. The informants chosen to complete this research data were speakers of the Mandailing language in their 50s and 60s. The selection of speakers in their 50s and 60s is based on an assumption that this generation can still obey the rules well.

In collecting data, it is used to note the note technique (Sudaryanto, 1988: 15-20) by listening to the use of various forms of Mandailing language lexeme which states the meaning of hand activity. In addition, the data were obtained through a capable method which was parallel with the interview method (Sudaryanto, 1988: 7). In this case, the researcher conducted a conversation with the informants by presenting lexemes which were considered difficult to know by their meaning components. The definition of the lexeme is explained, then the informant is requested to provide a response to the definition with a statement of true, false, or doubtful on the definition. The informant is requested to comment in order to improve the definition that has been submitted. If the definition is considered correct, the informant is requested to make a sentence as an example of using the correct lexeme.

All data obtained is recorded and ordered. The data that has been recorded on the data card is classified based on the similarity of the lexical semantic component.

\section{Discussion}

Language, Social identity and Religion are three major concerns of cultural studies. Language in literary texts plays a major role in constructing meaning and reflecting the author's intention. Likewise religion as a cultural politics is a dominant factor in shaping mind as well in affecting the framework of literary text. Religion is one of the emerging issues in the modern era and forms the backbone of most literary works. Religion as a theme is seen to influence the operation of those who believe in it. It forms the functional framework that predetermines ones actions and behavior. Furthermore, social identity decides on the status of the social class and their material life situation. Social identity relates to how we identify ourselves in relation to others according to what we have in common (Gaeini, et al: 2019).

Starting from the formulation of the problem and the purpose of the study, twenty subdomain were found in this study. Some sub- domain have only one lexeme and some have more than one lexeme. Sub- domain that only have one lexeme, namely (1) giving, (2) receiving, (3) calling, (4) casting out, (5) greeting, and (6) pointing. These six sub- domain 
certainly do not have what is called the superordinate lexeme and subordinate lexeme. Meanwhile, other sub- domain which have two or more lexemes usually one of the lexemes becomes superordinate and the other becomes a subordinate lexeme. However, there are also sub- domain who have two or more lexemes but do not have superordinate lexemes. Subdomain like this are called sub- domain with superordinate zero.

Sub-domain of hand activity to hold has nine lexemes. Judging from the components of meaning it possesses, the tiop "hold" lexeme is the superordinate in this group. The classifying semantic characteristic owned by the tiop lexeme and which also characterizes the semantics of the lexeme subordinates is the existence of a component of hand activity and a component of the meaning of the target's purpose.

Semantic domain of hand activity to hold has nine lexemes. The nine lexemes are as follows.

$\begin{array}{ll}\text { tiop } & \text { 'pegang' } \\ \text { golom } & \text { 'genggam' } \\ \text { pohul } & \text { 'kepal' } \\ \text { tangkup } & \text { 'tangkap' } \\ \text { kaol } & \text { 'peluk, rangkul' } \\ \text { kaluk } & \text { 'peluk, rangkul' } \\ \text { kubak } & \text { 'kupas' } \\ \text { abing } & \text { 'gendong, bopong' } \\ \text { ompa } & \text { 'gendong' }\end{array}$

If seen from the components of meaning possessed by the above mentioned lexemes, they all have a component of hand activity and a component of meaning purpose: strengthened targets. Based on the characteristic component of its generic meaning, the lexeme that becomes the superordinate in this group is the tiop "hold"

a. Tiop "Hold" Lexeme

Tiop "hold" is a lexeme that is used to hold generally. The tiop lexeme is the basic form and the active form of maniop is 'holding'.

The tiop lexeme has a component of meaning which is + holding activity + any target. In general, tiop lexeme can be explained as an act or activity of the hand to hold anything.

The use of tiop lexeme can be seen in the following example sentence.

1. Tiop jolo tas on santongkin, giot tu kamar mandi au.

pegang dulu tas ini sebentar, mau ke kamar mandi aku

"Hold this bag for a moment, I'm going to the bathroom!"

2. Harani biarna ditiop ia togos tangan ni umaknia.

karena takutnya dipegang dia kuat-kuat tangan ibunya

"Out of fear, he held his mother's hand tightly."

3. Jop roha ni anggi maniop baju na imbaru $i$.

senang hati adik memegang baju yang baru itu

"The younger sister likes to hold the new clothes."

b. Golom "Grip" Lexeme

Golom lexeme has a component of meaning, namely + finger pressing into the hands + inclusion of targets in the grip. Based on the components of its meaning, the golom lexeme means the activity of the hand to hold with fingers pressing the target into the palm of the hand and the target is covered in the grip. 
The use of golom lexeme can be seen in the following sentence example.

1. Golom jolo ubat ni ompung on! genggam dulu obatnya nenek ini

"Grab this grandma's medicine first!"

2. Awas matapor pira manuk na digolommi. awas pecah telur ayam yang digenggammu itu

"Beware of the broken chicken egg that you hold in your hand!"

3. Biasi digolom-golom ho unte i?

mengapa digenggam-genggam kau jeruk itu

"Why are you grappling with those oranges?"

c. Pohul "Fist" Lexeme

Pohul lexeme has a component of meaning, which is finger pressing targets to the hands of hands + strength finger presses + inclusion of targets in the grades. Generally pohul lexeme means hand activity to hold with fingers pressing the target firmly into the palm of the hand until the fingers touch the palm and the target is covered in the grip.

The use of pohul lexeme can be seen in the following example sentences.

1. Angkang manolongi umak mamohul itak di dapur.

kakak membantui ibu mengepal itak di dapur

"Sister helps mom clenching it in the kitchen."

2. Dipohul-pohul ia indahan i baru dipangan ia.

dikepal-kepal dia nasi itu baru dimakan dia

"The rice was clenched and then eaten."

3. Aha do na dipohul ni umak $i$ ?

apa yang dikepal ibu itu

"What is the fist mother?"

d. Tangkup "Capture" Lexeme

Tangkup lexeme has a component of meaning, namely + motivation to stop target movement + capture target attendance + reflection of movement. In general, the tangkup lexeme means the activity of the hand to hold with the specific purpose of capturing because it accepts the presence of a target and stops the target's motion accompanied by a reflection of motion.

The use of tangkup lexeme can be seen in the following sentence example.

1. Anggi malo manangkup siri-siri.

adik pandai menangkap capung

"A clever little brother to catch dragonflies."

2. Ma ditangkup hamu manuk na malua i?

sudah ditangkap kalian ayam yang lepas itu

"Have you caught the loose chicken?"

3. Madabu noma kiper i manangkup bal $i$.

terjatuh kiper itu menangkap bola itu

"The keeper falls to catch the ball."

e. Kaol "Embrace, Hug" Lexeme

Kaol lexeme has a component of meaning, namely + hand circle on target + done both hands. In general, lexeme kaol means hand activity to hold the hand looped on the target. 
The use of lexeme kaol can be seen in the following sentence examples.

1. Harani ngalina si Udin modom mangkaol bantal. karena dinginnya si Udin tidur memeluk bantal "Because it's cold, Udin is sleeping hugging a pillow."

2. Dikaol ia dongannia na dung leleng inda marsuo. dirangkul dia kawannya yang sudah lama tidak berjumpa

"He embraced a friend who hadn't seen him for a long time."

3. Ulang kaol-kaol au! jangan rangkul-rangkul aku' "Don't hug me."

f. Kaluk "Embrace, Hug" Lexeme

Kaluk lexeme has a component of meaning, namely + hand circle on target + done both hands + target: human. In general, kaluk lexeme has the meaning of hand activity to hold the hand looped on target.

The use of lexeme kaluk can be seen in the following example sentence.

1. Dikaluk ia anaknia togos harani lungunna. dipeluk dia anaknya erat karena rindunya "He hugged his child tightly because he missed."

2. Tarsonggot dongannia dikaluk ia sian bolakang. terkejut kawannya dipeluk dia dari belakang "His friend was surprised to hug him from behind."

3. Habis marsijalangan halahi pe marsikalukan. habis bersalaman mereka pun berpelukan

"After shaking hands, they embraced."

g. Kubak 'Peel' Lexeme

Kubak lexeme has a component of meaning, namely + mother finger and bending + a little target + targeting target. In general, the kubak lexeme means the activity of the hand to hold in the way of the thumb and forefinger holding the target slightly and then pulling it.

The use of cubic lexeme can be seen in the following example sentence.

1. Kubak pe sada salak $i$ di anggimu! kupas dulu satu salak itu untuk adikmu

"Let me know that one bark is for your sister!"

2. Ise de mangkubak honas on? siapa mengupas nenas ini

"Who is peeling this pineapple?"

3. Pisang na giot sonopon i madung dikubak si Irma. pisang yang mau dikolak itu sudah dikupas si Irma

"The banana that will be turned away has already been peeled off by Irma."

h. Abing 'Carrying, Bopong' Lexeme

Abing lexeme has a component of meaning, namely + done both hands + targets + hold / carry motivation. In general, lexeme abing means hand activity to hold and carry the target with both hands in front of the chest.

The use of lexeme abing can be seen in the following sentence example.

1. Jop noma dilala si Ani mangabing anak ni huting $i$. senang sekali dirasa si Ani menggendong anak kucing itu. 
"So glad that Ani was holding the kitten."”

2. Abing jolo anggimu anso mardahan umak! gendong dulu adikmu supaya memasak ibu

"Carrying your sister first so I can cook!"

3. Aha de na diabingmi?

apa yang dibopongmu itu

"What are you carrying?"

i. Ompa " Carrying " Lexeme

Ompa Lexeme has a component of meaning, namely + hand circle on targets + targets pressed to hips + motivation hold / bring + honest target: children. In general, lexeme ompa means hand activity to hold and carry the target with both hands looped to the target and the target pressed to the hip.

The use of lexeme abing can be seen in the following sentence example.

1. Diompa si Ani angginia tu pasar.

digendong si Ani adiknya ke pasar.

'Si Ani carried her sister to the market.'

2. Ompa jolo si Uncok sanongkin! gendong dulu si Uncok sebentar "Hold the Uncok for a while!"

3. Jago malua na diabingmi! awas lepas yang digendongmu itu "Watch out what you're carrying!"

\section{Conclusion}

The lexemes which stated the hand activity in Mandailing language which had been inventoried were eighty-five lexemes. These lexemes are classified based on the components of the meaning they have so as to form groups or more sub-domain specific meanings. From the study, there were twenty groups of sub-domain meanings based on the purpose of the activity, namely (1) holding, (2) touching, (3) taking, (4) carrying, (5) laying, (6) throwing, (7) giving, (8) receiving, (9) opening, (10) closing, (11) pulling, (12) pushing, (13) hurting, (14) destroying, (15) rolling, (16) calling out, (17) expelling, (18) ) blocking, (19) greeting, and (20) pointing.

Components of semantic classifier meanings or characteristics possessed by each group or sub-domain meaning of hand activity in Mandailing language are as follows.

maniop 'holding': + hand activity + goal: target locked; 


\section{References}

Alwasilah, A. C. (1984). Linguistik: Suatu Pengantar. Bandung: Angkasa.

Alwi, H. and Sugono, D. (2003). Politik Bahasa, Risalah Seminar Politik Bahasa. Jakarta: Progres dan Pusat Bahasa Depdiknas.

Aminuddin. (1988). Semantik: Pengantar Studi Tentang Makna. Bandung: Sinar Baru.

Basiroh, U. (1992). Telaah Baru dalam Tata Hubungan Leksikal Kehiponiman dan Kemeroniman. Thesis. Jakarta: Fak. Pascasarjana UI.

Chaer, A. (1994). Pengantar Semantik Bahasa Indonesia. Jakarta: Rineka Cipta.

Endarmoko, E. (2006). Tesaurus Bahasa Indonesia. Jakarta: Gramedia Pustaka Utama.

Gaeini, M., Soqandi, M., and Basirizadeh, F., S. (2019). The Role of Language and its Analysis in James Joyce's Dubliners within the Light of Cultural Materialism. Budapest International Research and Critics in Linguistics and Education Journal. Vol. 2, No. 2, 16-26.

Kridalaksana, H. (1993). Kamus Linguistik. Jakarta: Gramedia.

Larson, M. (1984). Penerjemahan Berdasarkan Makna: Pedoman untuk Pemadanan Antarbahasa. Translated by Kencanawati Tarigan. Jakarta: Arcan.

Lehrer, A. (1974). Semantic Field and Lexical Structure. Amsterdam: Nort-Holland Publishing Company.

Nida, E. A. (1975). Componential Analysis of Meaning: Introduction to Semantic Structure. Mouton: The Hague Bards.

Nurlina, W., E., S. (1993). Medan Makna Aktivitas Pancaindra dalam Bahasa Jawa. Yogyakarta: Balai Penelitian Bahasa.

Pateda, M. (1989). Semantik Leksikal. Ende-Flores: Nusa Indah.

Program Studi Linguistik PPs USU. (2004). Tata Cara Penulisan Tesis dan Disertasi. Medan: PPs USU.

Setiyanto, E. (1997). Medan Makna Aktivitas Tangan dalam Bahasa Jawa. Jakarta: Pusat Pembinaan dan Pengembangan Bahasa, Depdikbud.

Sevilla, C., G. (1993). Pengantar Metode Penelitian. Penerjemah Alimuddin Tuwu. Jakarta: UI Press.

Siregar, A., S. (1977). Kamus Bahasa Angkola/Mandailing - Indonesia. Jakarta: Pusat Pembinaan dan Pengembangan Bahasa, Depdikbud.

Subroto, D., E. (1991). Semantik Leksikal I dan II. Surakarta: Universitas Sebelas Maret.

Sudaryanto. (1988). Metode Linguistik: Metode dan Aneka Teknik Pengumpulan Data. Yogyakarta: Gadjah Mada University Press.

ᄀ__. (1993). Metode dan Aneka Teknik Analisis Bahasa. Yogyakarta: Duta Wacana.

Tim Penyusun Kamus Pusat Bahasa. (2005). Kamus Besar Bahasa Indonesia. Edisi Ketiga. Jakarta: Balai Pustaka.

Uhlenbeck, E., M. (1982). Ilmu Bahasa, Pengantar Dasar. Translated by Alma E. Almanar. Jakarta: Djambatan.

Wedhawati. (1990). "Pandangan E.A. Nida: Analisis Komponen Makna, Sebuah Ulasan Singkat”. Dalam Widyaparwa No. Khusus Tahun 3. 